\title{
Menemukenali Leksikon-leksikon Arkais pada Bidang Obat-obatan Tradisional Bali
}

\author{
I Made Netra \\ Universitas Udayana \\ Email: imadenetra@unud.ac.id
}

\author{
Abstract \\ The Exploration of Archaic Lexicons of Cultural Practices \\ in the Field of Balinese Traditional Medicine
}

This article aims to identify types of archaic lexicon in the Balinese cultural practices of traditional medicine and configure their meanings. Data were obtained by participatory observation method with note-taking and recording techniques. Lists of archaic lexicons existing in 10 fields of Balinese cultural practices were taken from a questionnaire given to 80 respondents spread in Buleleng and Gianyar districts. The analysis showed that 11 archaic lexicons were found in the field of Balinese traditional medicine. They are classified into archaic lexicons because of the incomprehension of the younger generation regarding the existence of their artifacts and use in society even though they are still found and used in rural areas. Therefore, they are not yet categorized as extinct. The conceptual configuration of the lexicon can be made based on a cultural scripts approach with the "if ...... then" component and exponent description, such as entities, ways of creation, results, and functions

Keywords: archaic lexicon, artifacts, medicine, young generation, geographical areas

\begin{abstract}
Abstrak
Artikel ini bertujuan untuk mengidentifikasi leksikon arkais pada praktik budaya bidang obat-obatan tradisional Bali dan mengkonfigurasi maknanya. Data diperoleh dengan metode observasi partisipatif dengan teknik catat dan rekam. Daftar leksikon arkais tersebar dalam 10 bidang praktik budaya Bali diperoleh dari kuesioner yang diberikan kepada 80 responden yang tersebar di dua kabupaten, yaitu Kabupaten Buleleng dan Kabupaten Gianyar. Hasil analisis menunjukkan bahwa sebelas leksikon arkais ditemukan pada bidang obat-obatan tradisional
\end{abstract}


Bali karena ketidaktahuan generasi muda akan keberadaan artefaknya dan ketidakpahaman mereka akan penggunaannya walaupun artefaknya masih ada dan masih digunakan di daerah pedesaan saja dan tidak ditemukan lagi di daerah perkotaan. Kesebelas leksikon arkais tersebut belum dikategorikan punah karena masih memiliki konsepsi dan artefaknya pun masih bisa dimanfaatkan. Konfigurasi leksikon dapat dibuat berdasarkan pendekatan cultural scripts dengan komponen "jika ......maka" dan uraian eksponen, seperti cara, mekanisme pembuatan, hasil, dan fungsinya.

Kata kunci: leksikon arkais, artefak, obat-obatan tradisional Bali, generasi muda, letak geografi

\section{Pendahuluan}

Rahasa mengalami evolusi dari waktu ke waktu. Evolusi Bini bisa terjadi pada tataran gramatika. Aitchison (1994) mengatakan bahwa yang termasuk di dalam gramatika adalah fonologi, morfologi, sintaksis, dan semantik. Khusus pada tataran morfologi, evolusi bisa terjadi pada tingkat leksikon. Dalam hal ini, leksikon dapat berevolusi secara alami. Evolusi secara morfologis dapat terjadi dalam hal wujud dan penamaannya yang dilengkapi dan didukung dengan artefaknya. Menurut Kamus Besar Bahasa Indonesia, ada kalanya leksikon yang bersifat kuno atau antik dianggap sebagai leksikon arkais.

Penelitian tentang leksikon arkais sudah banyak dilakukan para peneliti, seperti Wahab (2015) dalam artikel "Bahasa Melayu Jambi di Kabupaten Sarolangun: Kajian Deskriptif". Yulis dkk. (2017) menulis kajian berjudul "Analysis of Dead Words of Minangkabaunese in Koto Tabang-Par". Berdasarkan rangkuman beberapa hasil penelitian, leksikon arkais merupakan kata yang antik, kuno, dan tidak digunakan lagi. Bagaimanapun ada fenomena kebahasaan terutama di Bali bahwa leksikon arkais itu bisa ditentukan berdasarkan pemahaman penggunaannya oleh generasi muda dan juga keberadaan artefaknya, serta letak geografi tempat leksikon dan artefak tersebut digunakan, seperti daerah 
pedesaan dan daerah perkotaan (Netra, 2018).

Berdasarkan fenomena di atas, dalam artikel ini konsepsi arkais yang diacu adalah yang berdasarkan variabel yang sudah baku secara sosiolinguistik, yaitu arkais berdasarkan pemahaman pengguna yang berasal dari kalangan generasi muda dan arkais berdasarkan keberadaan artefak di daerah pedesaan dan atau daerah perkotaan. Dilihat dari sisi penggunaannya, leksikon arkais tersebut merupakan leksikon yang sebenarnya masih ditemukan dan digunakan di tengah kehidupan masyarakat, namun penggunaannya masih terbatas oleh pengguna generasi tua saja, di mana artefak leksikon arkais tersebut digunakan baik di daerah pedesaan atau di daerah perkotaan.

Leksikon arkais dan artefaknya, khususnya di Bali, masih ditemukan dan digunakan di berbagai praktik budaya Bali. Praktik budaya Bali termasuk di dalamnya berbagai bidang kehidupan masyarakat, seperti rumah tangga, pertanian, adat dan agama, makanan/minuman, akomodasi/arsitektur Bali, olah raga/permainan, obat-obatan tradisional, ekonomi/perdagangan, transportasi, dan pendidikan. Artefak dari leksikon arkais pada praktik budaya Bali ini merupakan wujud kebudayaan Bali. Secara budaya, dapat dikatakan bahwa artefak dari leksikon arkais tersebut merupakan realita budaya.

Leksikon arkais yang tersebar di seluruh bidang praktik budaya Bali tersebut masih memiliki konsep atau makna yang hanya dipahami oleh generasi tua. Oleh karena itu, untuk mempertahankan dan mengembangkan leksikon tersebut terutama peningkatan pemahaman sampai kepada kalangan generasi muda, maka perlu dibuatkan eksplikasi dan atau konfigurasi makna leksikon tersebut sehingga seluruh leksikon arkais itu tidak mengarah pada kepunahan. Untuk mengkonfigurasi makna leksikon ini diperlukan sebuah model yang sudah banyak diteliti sebelumnya oleh para ahli linguistik. Model ini diawali oleh Wierzbicka (1999) dengan teori Natural Semantic Metalanguage dan Goddard (2004) dengan teori Cultural Scripts. Dalam tulisan ini yang digunakan adalah teori Cultural Scripts dari Goddard. 
Berdasarkan latar belakang di atas, artikel ini menganalisis aspek bentuk dan makna leksikon arkais pada praktik budaya khususnya di bidang obat-obatan tradisional Bali dan mendeskripsikan serta mengkonfigurasi makna leksikon arkais tersebut. Bidang obat-obatan tradisional Bali dipilih antara lain karena alasan menguatnya kecenderungan untuk penggunaan herbal dan obat-obatan tradisional dalam kehidupan modern dewasa ini, termasuk di Bali.

\section{Kerangka Pikir dan Metode}

Ada dua teori yang diterapkan dalam artikel ini. Kedua teori ini dapat dijadikan kerangka berpikir untuk menjawab permasalahan terkait identifikasi kearkaisan leksikon dan konfigurasi makna leksikon tersebut. Permasalahan terkait jenis leksikon arkais dijelaskan berdasarkan teori Sosiolinguistik Kontekstual. Permasalahan terkait konfigurasi makna leksikon diuraikan berdasarkan teori Cultural Scrips

\subsection{Teori Sosiolinguistik Kontekstual}

Secara umum bahasa arkais didefinisikan sebagai bahasa yang digunakan karena adanya unsur-unsur dari zaman lampau yang tetap bertahan. Penggunaan bahasa arkais dimaksudkan untuk memberi corak atau warna agar menarik perhatian pembaca dan pendengar, dengan syarat maksud dan pesan yang ingin disampaikan bisa tersampaikan dan disesuaikan dengan situasi dan nilai rasa yang dimiliki sekelompok masyarakat agar tidak merusak suasana atau menyinggung perasaan orang yang tidak hadir. Jadi, parameter arkais yang dipakai adalah (1) berhubungan dengan masa dahulu atau berciri kuno, tua; (2) tidak lazim dipakai lagi (tentang leksikon); ketinggalan zaman. Bagi generasi muda masa kini, mungkin masih sangat asing dengan istilah arkais. Leksikon arkais merupakan kata-kata yang berhubungan zaman dahulu atau leksikon-leksikon yang sudah tidak lazim atau bisa dikatakan leksikon kuno.

Sejalan dengan pendapat ini, para ahli sosiolinguistik 
memberikan beberapa variabel yang baku terkait dengan penggunaan bahasa di dalam masyarakat. Oleh karena itu, untuk mengidentifikasikan kearkaisan leksikon, bisa didekatkan dengan SosiolinguistikKontekstual(Holmes, 2013). Teoriinimenitikberatkan kajian bahasa yang berkaitan dengan masyarakat, Dalam hal ini penggunaan bahasa dalam masyarakat juga dikaji. Penggunaan bahasa ditentukan dengan atau berdasarkan konteks penggunaan dengan menerapkan variabel yang sudah tetap dan pasti. Variabelvariabel seperti usia, kalangan generasi, pendidikan, jenis kelamin, tempat, letak geografi, dan sebagainya merupakan variablel yang sudah berterima dan sudah baku.Variabel tersebut dapat digunakan sedemikian rupa sehingga menyebabkan terjadinya variasi bahasa, unda usuk bahasa, dan sebagainya. Teori ini dapat dimodifikasi atau diadopsi dan diterapkan sebagai kerangka untuk menentukan parameter kearkaisan sebuah leksikon.

\subsection{Teori Cultural Scripts}

Wierzbicka (1996) mengatakan bahwa sebuah leksikon tertentu memiliki makna yang universal dan alami. Sebagai contoh, konsep kata say dalam bahasa Inggris yang berfungsi untuk memberikan pernyataan atau menyatakan, dapat diparafrasekan dengan (1) saya menyatakan sesuatu untuk anda; (2) orang menyatakan suatu yang buruk tentang anda; dan (3) saya ingin menyatakan sesuatu sekarang. Wierzbicka (1996) mengatakan bahwa meskipun pola-pola gramatikal suatu bahasa bersifat spesifik, selalu dapat ditemukan pola-pola yang universal. Pola-pola gramatikal universal ini dinyatakan sebagai seperangkat kalimat dasar 'basic sentence' dalam aneka bahasa. Kalimat dasar ini dibangun oleh elemenelemen leksikon universal. Relasi elemen-elemen leksikon universal berdasarkan gramatika suatu bahasa disebut dengan sintaksis MSA (Metabahasa Semantik Alami). Lebih lanjut, dirumuskan prinsipprinsip sintaksis MSA, seperti berikut: (1) setiap pola diprediksi ada pada bahasa-bahasa di dunia; (2) pola-pola itu merupakan tata bahasa bawaan innate grammar dari kognisi manusia; dan (3) menggunakan leksikon semantik universal 
Pada masyarakat yang berbeda, orang atau sekelompok orang tidak hanya memakai bahasa yang berbeda, tetapi mereka menggunakan bahasa-bahasa tersebut dengan cara-cara yang sangat berbeda pula. Cultural scripts dikategorikan menjadi 2 jenis, yaitu high-level script dan low-level script (Wierzbicka, 2002). High-level script merupakan master script. Master script di dalam masyarakat dianggap sebagai wacana inti yang berisikan praktikpraktik budaya yang dapat digunakan sebagai pedoman atau model untuk mengetahui norma adat dan budaya. Kedua jenis cultural scripts tersebut berhubungan dengan komponen makna asali evaluasi, seperti "Hal itu bagus jika...", dengan varian, seperti: "Hal itu tidak bagus jika...", "Hal itu buruk jika...", Hal itu akan "menjadi bagus jika...". Di samping itu, komponen persepsi manusia juga bisa digunakan untuk menjelaskan norma budaya. Persepsi yang dimaksud adalah "Saya dapat mengatakan (memikirkan, melakukan, dll)..." Saya tidak dapat mengatakan (memikirkan, melakukan, dll)...". Jenis cultural scripts yang lowlevel script cenderung dibuat dengan komponen "ketika" dan "jika" (Goddard, 2004: 6).

\subsection{Metode Penelitian}

Metode yang digunakan untuk memperoleh data adalah metode observasi partisipasif (Bungin,2001: 57; Moleong, 2000) dengan teknik catat dan rekam. Data diperoleh dari 80 responden yang tersebar di dua daerah kabupaten, yaitu Kabupaten Buleleng dan Kabupaten Gianyar. Pemilihan kedua daerah kabupaten ini sebagai lokasi penelitian berdasarkan teknik sample terpancang (purposive sampling) (Bungin, 2003). Dipilihnya Kabupaten Buleleng merupakan sampel dari Bali Utara terutama mewakili daerah pedesaan, sedangkan Kabupaten Gianyar dipilih sebagai sampel dari Bali Selatan terutama di daerah perkotaan. Kuesioner diberikan kepada 40 orang generasi muda yang tinggal di daerah pedesaan di Kabupaten Buleleng dan 40 orang generasi muda yang tinggal di daerah perkotaan di Kabupaten Gianyar.

Kuesioner yang diberikan bersifat tertutup dan terbuka. Pada 
bagian yang tertutup, responden diberikan daftar leksikon yang dianggap arkais kemudian dilihat pemahaman generasi muda terhadap keberadaan leksikon tersebut, makna dan penggunaannya di masyarakat. Pada bagian yang terbuka, responden juga diminta untuk menambahkan leksikon yang terkait praktik budaya Bali pada bidang obat-obatan tradisional Bali yang dikategorikan arkais. Selanjutnya, wawancara mendalam dilakukan kepada informan yang daftar pertanyaan sudah disiapkan sebelumnya. Pertanyaan hanya menyasar keberadaan leksikon arkais, makna, dan penggunaanya di masyarakat. Informan yang ditemukan adalah satu orang yang berprofesi sebagai ahli dan sekaligus praktisi budaya Bali. Data yang diperoleh adalah berupa daftar leksikon yang dikategorikan arkais yang tersebar pada 10 bidang praktik budaya Bali. Dari keseluruhan jumlah leksikon arkais pada sepuluh bidang praktik budaya Bali tersebut, leksikon arkais pada bidang obat-obatan tradisional Bali saja yang dieksplorasi. Setelah data diperoleh dan diklasifikasikan, maka langkah selanjutnya adalah melakukan kodifikasi data. Kemudian, data tersebut dianalisis secara sistematis berdasarkan urutan permasalahan yang diformulasikan. Pertama yang dikaji dalam artikel ini adalah identifikasi leksikon arkais pada praktik budaya Bali bidang obatobatan berdasarkan teori Sosiolinguistik Kontekstual. Selanjutnya diuraikan konfigurasi makna berdasar teori Cultural Scripts. Metode yang digunakan adalah metode padan dengan alat bantu yang berupa tulisan atau teori-teori yang relevan dan metode agih, yaitu metode yang alat bantunya justru bagian dari bahasa itu sendiri dengan menerapkan teknik dasar, yaitu teknik pilah unsur-unsur penentu (Sudaryanto, 2003).

\section{Pembahasan}

Bagian ini menguraikan dua aspek kajian, yaitu kajian terhadap identifikasi leksikon arkais pada praktik bdaya Bali bidang obatobatan tradisional Bali dan konfigurasi makna leksikon arkais. Kedua kajain ini disajikan secara terpisah. Kajian tentang identifikasi leksikon arkais bidang obat-obatan disajikan terlebih dahulu, 
kemudian diikuti dengan konfigurasi makna leksikon arkais.

\subsection{Identifikasi Leksikon Arkais Bidang Obat-Obatan Tra- disional Bali}

Modifikasi terhadap konsepsi arkais dapat dibuat untuk memberikan kejelasan parameter yang diacu sehingga mampu melihat dan mengisi kesenjangan (gap) yang terjadi. Modifikasi semacam ini dapat dijadikan variabel dan parameter untuk menentukan kearkaisan sebuah leksikon. Variabel dan parameter yang dimaksud adalah:

1. Leksikon dapat diklasifikasikan arkais apabila leksikon dan artefaknya masih ada dan digunakan di daerah pedesaan dan perkotaan. Pengguna dari kalangan generasi muda tidak mengetahui keberadaan leksikon dan artefaknya dan bahkan mereka tidak memahami makna leksikon dan penggunaannya.

2. Leksikon dapat diklasifikasikan arkais apabila leksikon dan artefaknya masih ada dan digunakan di daerah pedesaan saja, tetapi tidak ditemukan dan digunakan lagi di daerah perkotaan. Dalam hal ini, pengguna dari kalangan generasi muda tidak mengetahui keberadaan leksikon dan artefaknya dan bahkan mereka tidak memahami makna leksikon dan penggunaannya.

3. Leksikon dapat diklasifikasikan arkais apabila leksikon dan artefaknya tidak ada dan tidak digunakan lagi di daerah pedesaan, tetapi ditemukan dan digunakan di daerah perkotaan, dengan variasi artefaknya. Dalam hal ini, pengguna dari kalangan generasi muda tidak mengetahui keberadaan leksikon dan artefaknya dan bahkan mereka tidak memahami makna leksikon dan penggunaannya

4. Leksikon dapat diklasifikasikan arkais apabila leksikon dan artefaknya tidak ada dan tidak digunakan lagi di daerah pedesaan dan di daerah perkotaan. Dalam hal ini, bahkan pengguna dari kalangan generasi muda tidak mengetahui keberadaan leksikon dan artefaknya dan bahkan mereka tidak memahami makna leksikon dan penggunaannya 
Identifikasi bentuk dan jenis leksikon praktik budaya Bali bidang obat-obatan tradisional Bali yang dikategorikan arkais sesuai dengan parameter yang telah dibuat berdasarkan konsepsi sosiolinguistik kontekstual dapat dilihat dalam gambar berikut ini.

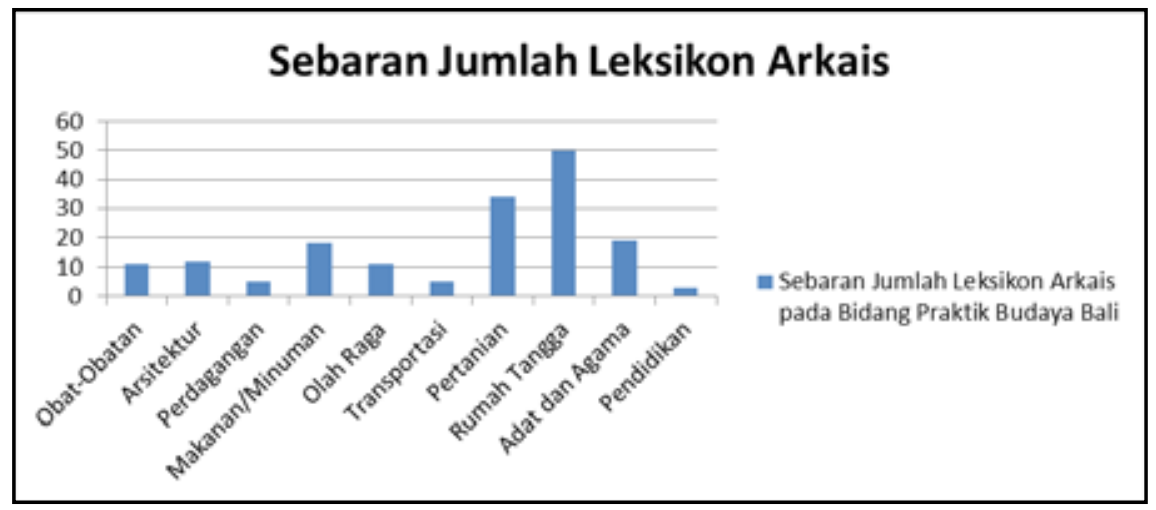

Grafik 1. Sebaran jumlah leksikon arkais.

Grafik 1 menunjukkan bahwa leksikon arkais tersebar dalam 10 bidang praktik budaya Bali. Kesepuluh bidang praktik budaya Bali adalah obatan-obatan, arsitektur, perdagangan, makanan/ minuman, olah raga, transportasi, pertanian, rumah tangga, adat dan agama, dan pendidikan. Data menunjukkan bahwa sebaran jumlah leksikon arkais pada bidang praktik budaya Bali adalah: obat-obatan sebesar 11 buah, arsitektur 12 buah, perdagangan 5 buah, makanan/minuman 18 buah, olah raga 11 buah, transportasi 5 buah, pertanian 34 buah, rumah tangga 50 buah, adat dan agama 19 buah, dan pendidikan 3 buah.

Setelah dilakukan perangkuman pada semua bidang praktik budaya Bali jumlah keseluruhan leksikon arkais adalah berjumlah 168 (seratus enam puluh delapan). Dari jumlah keseluruhan leksikon arkais, tampak bahwa dalam bidang obat-obatan ditemukan 11 (sebelas) leksikon arkais (bar paling kiri) atau sebesar enam koma lima puluh lima persen $(6,55 \%)$. Kesebelas leksikon tersebut adalah borèh, pupuk, tèrèk, odak, simbuh, loloh, tutuh,karas, panawar, asaban, dan kumkuman. Kearkaisan leksikon bahasa Bali dapat ditentukan berdasarkan parameter yang mengacu pada 
variabel sosiolinguistik. Berikut disajikan parameter atau variabel yang menentukan kearkaisan leksikon terutama leksikon bidang obat-obatan.

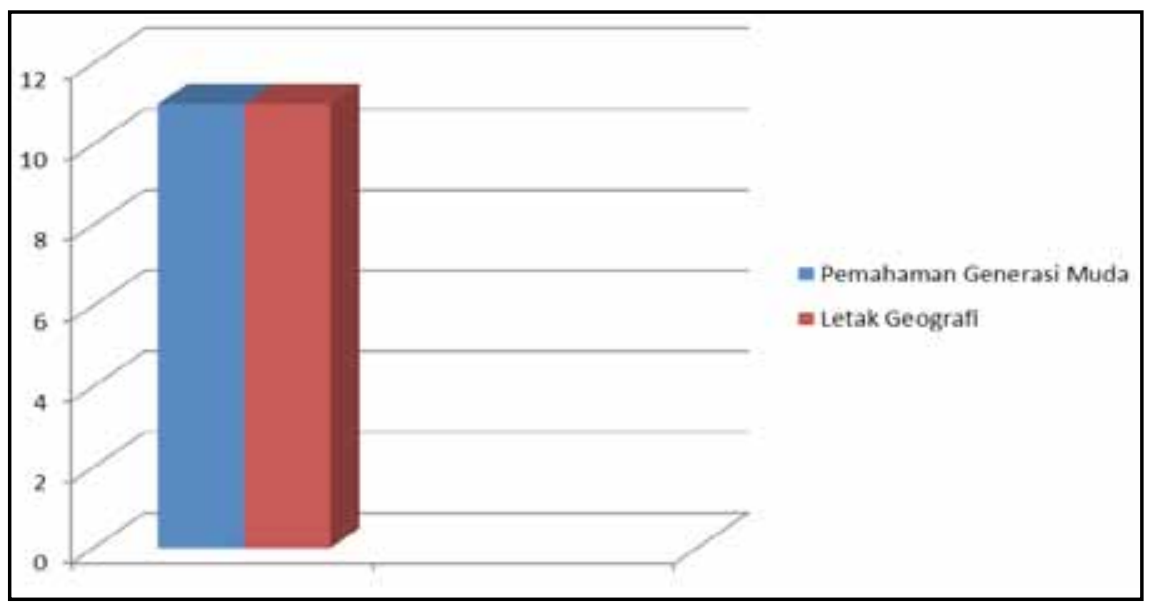

Grafik 2. Leksikon Arkais Bidang Obat-Obatan

Grafik 2 menunjukkan bahwa ada sebelas leksikon arkais bidang obat-obatan tradisional Bali. Kesebelas leksikon (100\%) dikategorikan arkais berdasarkan ketidakmengertian dan ketidakpahaman generasi muda terhadap keberadaan leksikon, makna, dan penggunaannya di samping itu, kesebelas (11) leksikon atau sebesar $100 \%$ arkais juga ditentukan dari penemuan dan penggunaannya di daerah pedesaan saja bukan di daerah perkotaan. Kesebelas leksikon arkais bidang obat-obatan tradisional Bali dapat dilihat berikut ini.

(3-1) borèh

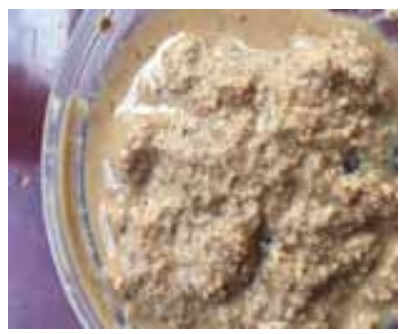

(Foto I Made Netra, 2018).
Ramuan yang dibuat dari berbagai bahan dari daun-daunan, akarakaran, ranting pohon, kulit pohon, dan umbi-umbian dan rempah-rempahcyang sudah diolah sedemikian rupa, biasanya diulek di atas tempat tertentu yang terbuat dari batu, dan bisa digunakan sebagai lulur yang digosokkan atau dilulurkan ke sekujur tubuh atau pada bagian tubuh yang sakit saja, sehingga tubuh atau bagian tubuh tersebut terasa lebih fit atau lebih segar. 
Berdasarkan hasil survey, leksikon borèh dan artefaknya masih tetap ada dan digunakan di daerah pedesaan, dan tidak ditemukan dan digunakan lagi di daerah perkotaan. Penggunaan borèh di daerah pedesaan oleh pengguna dan masyarakat pedesaan yang berfungsi sebagai lulur untuk membuat badan terasa lebih fit dan segar. Namun demikian, pengguna dari kalangan generasi muda sama sekali tidak mengetahui konsep leksikon ini dan artefaknya di samping mereka tidak memahami makna dan penggunaannya. Namun demikian, khusus untuk pengguna di daerah perkotaan, borèh tidak diketahui lagi penggunaannya, akan tetapi sudah digantikan dengan lulur. Leksikon borèh memiliki dua buah varian, yaitu pupuk dan tèrèk.

(3-2) Pupuk

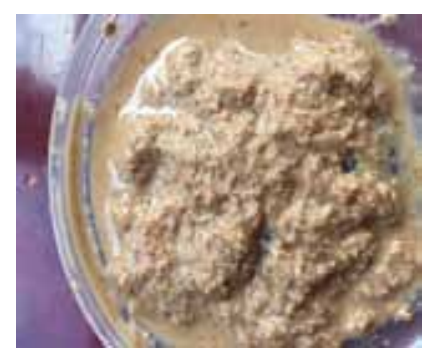

(Foto I Made Netra, 2018)
Ramuan yang dibuat dari berbagai bahan dari daundaunan, akar-akaran, ranting pohon, kulit pohon, dan umbiumbian dan rempah-rempah yang sudah diolah sedemikian rupa, biasanya diulek di atas tempat tertentu yang terbuat dari batu, dan bisa digunakan dengan menempelkannya pada ubun-ubun selama beberapa lama sampai kering dan sampai memberi perubahan pada pemulihan kesehatan terutama sakit kepala

Sama seperti borèh, pupuk merupakan bentuk varian dari borèh yang diklasifikasikan arkais karena leksikon pupuk sesuai dengan variable-variabel pemahaman generasi muda terhadap keberadaan leksikon ini dan makna serta penggunaannya. Berdasarkan hasil survey, leksikon pupuk dan artefaknya masih tetap ada dan digunakan di daerah pedesaan, dan tidak ditemukan dan digunakan lagi di daerah perkotaan. Penggunaan pupuk di daerah pedesaan oleh pengguna dan masyarakat pedesaan yang berfungsi sebagai obat penghalau rasa sakit dan badan yang terasa tidak fit dan segar. Namun demikian, pengguna dari kalangan generasi muda sama sekali tidak mengetahui konsep leksikon ini 
dan artefaknya di samping mereka tidak memahami makna dan penggunaannya. Khusus untuk pengguna di daerah perkotaan, pupuk tidak diketahui lagi penggunaannya, akan tetapi sudah digantikan dengan lulur.

\section{(3-3) tèrèk}

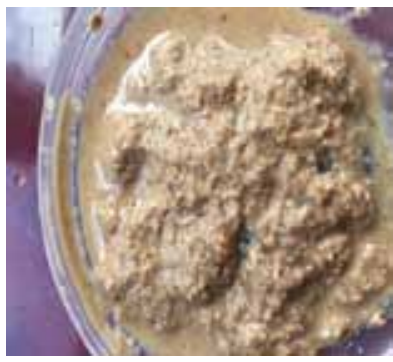

(Foto I Made Netra, 2018)
Ramuan yang dibuat dari berbagai bahan dari daundaunan, akar-akaran, ranting pohon, kulit pohon, dan umbiumbian dan rempah-rempah yang sudah diolah sedemikian rupa, biasanya diulek di atas tempat tertentu yang terbuat dari batu, dan bisa digunakan dengan menggosokkan atau melulurkannya pada dahi selama beberapa lama sampai kering dan memberi perubahan pada kesehatan yaitu membuat lebih segar dan menghalau sakit kepala

Sama seperti borèh, tèrèk merupakan bentuk varian dari borèh yang diklasifikasikan arkais karena leksikon tèrèk sesuai dengan variable-variabel pemahaman generasi muda terhadap keberadaan leksikon ini dan makna serta penggunaannya. Berdasarkan hasil survey, tèrèk dan artefaknya masih tetap ada dan digunakan di daerah pedesaan, dan tidak ditemukan dan digunakan lagi di daerah perkotaan. Penggunaan tèrèk di daerah pedesaan oleh pengguna dan masyarakat pedesaan yang berfungsi sebagai obat penghalau rasa sakit dan badan yang terasa tidak fit dan segar. Namun demikian, pengguna dari kalangan generasi muda sama sekali tidak mengetahui konsep leksikon ini dan artefaknya di samping mereka tidak memahami makna dan penggunaannya. Khusus untuk pengguna di daerah perkotaan, tèrèk tidak diketahui lagi penggunaannya, akan tetapi sudah digantikan dengan lulur. 
(3-4) odak

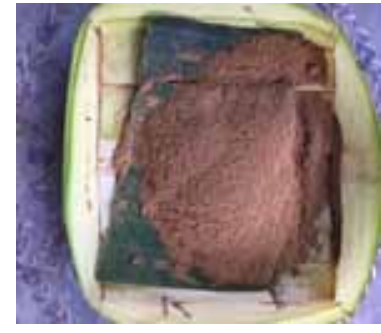

(Foto I Made Netra, 2018)
Ekstraksi ramuan yang dibuat dari gabungan berbagai bahan yang berasal dari daun-daunan, akar-akaran, ranting pohon, kulit pohon, dan umbi-umbian dan rempah-rempah yang sudah diolah sedemikian rupa, dan biasanya diulek pada tempat tertentu yang terbuat dari batu, dan bisa digunakan sebagai bedak yang kering yang setelah diolah dapat khusus dipakai di bagian muka

Sama seperti borèh, odak merupakan bentuk varian yang diklasifikasikan arkais karena leksikon odak sesuai dengan variablevariabel pemahaman generasi muda terhadap keberadaan leksikon ini dan makna serta penggunaannya. Berdasarkan hasil survey, odak dan artefaknya masih tetap ada dan digunakan di daerah pedesaan, dan tidak ditemukan dan digunakan lagi di daerah perkotaan. Penggunaan odak di daerah pedesaan oleh pengguna dan masyarakat pedesaan berfungsi sebagai obat penghalau rasa sakit, terutama digunakan bagian muka sehingga muka terasa lebih segar. Namun demikian, pengguna dari kalangan generasi muda sama sekali tidak mengetahui konsep leksikon ini dan artefaknya di samping mereka tidak memahami makna dan penggunaannya. Khusus untuk pengguna di daerah perkotaan, odak tidak diketahui lagi penggunaannya, akan tetapi sudah digantikan dengan bedak.

Sebagai alat kecantikan atau kesehatan muka, odak masih titemukan dan digunakan di desa tetapi tidak lagi ditemukan dan digunakan di kota karena sudah ada bedak yang modern yang digunakan untuk kesehatan dan kecatikan muka yang dirasakan jauh lebih efektif dan efisien. Masyarakat tidak perlu merasa susah untuk membuat dan mengolahnya lagi. Mereka bisa pergi ke toko obat membeli alat kecantikan yang lebih medis dan modern. Dengan demikian, generasi muda dipastikan tidak mengetahui dan memahami makna leksikon dan penggunaannya. 
(3-5) Simbuh

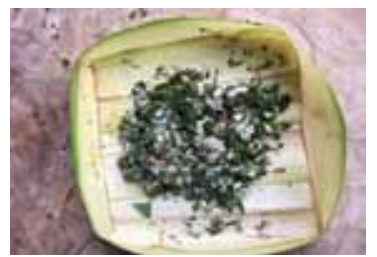

(Foto I Made Netra, 2018) ramuan dari gabungan berbagai bahan yang berasal dari tumbuhtumbuhan dan daun-daunan yang dipotong kecil-kecil dan diaduk menjadi satu dan berfungsi sebagai obat tradisional yang pengobatannya dilakukan dengan cara mengunyah dan menyemburkannya ke bagian tubuh yang dianggap sakit

Sebagai obat tradisional, simbuh hanya ditemukan dan digunakan di daerah pedesaan saja sementara tidak ditemukan dan digunakan di daerah perkotaan karena sudah ada obat gosok yang dipakai sebagai pengganti simbuh tersebut. Oleh karena itu, pengguna dari kalangan generasi muda tidak mengetahui dan memahami leksikon, makana dan penggunaannya.

(3-6) loloh

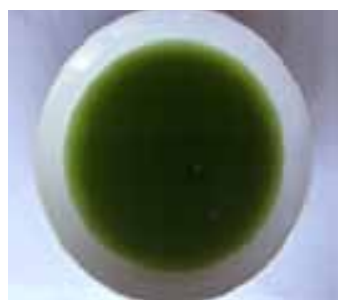

(Foto I Made Netra, 2018)
Sejenis cairan yang terbuat dari daun-daunan tertentu yang diremas kemudian disaring sehingga air dan ampas menjadi terpisah yang bisa dipakai sebagai obat dalam dengan cara diminum dan berfungsi sebagai obat panas dalam

Sebagai obat tradisional yaitu obat yang digunakan untuk menurunkan panas atau mengobati panas dalam, loloh masih ada dan digunakan di desa tetapi tidak lagi ada di kota karena sudah ada obat penurun panas dan penghilang panas yang lebih bersifat medis. Dengan demikian, pengguna leksikon ini yang berasal dari kalangan generasi muda pun tidak mengetahui dan memahami makna dan penggunaannya. 
(1-7) tutuh

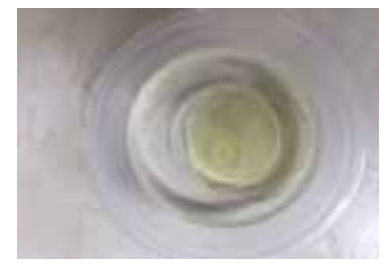

(Foto I Made Netra, 2018)
Sejenis ramuan yang terbuat dari getah pohon atau benda cair lainnya yang dipakai sebagai obat sakit kepala yang sengaja diteteskan ke mata pasien sehingga si pasien akan merasa lebih tenang

Sebagai obat tradisional yaitu obat sakit kepala,tutuh hanya ditemukan dan digunakan di daerah pedesaan dan penggunaannya sebagai obat tradisional penghilang sakit kepala yang membandel tetapi tidak ditemukan dan digunakan di kota lagi. Dengan demikian, dapat dikatakan bahwa pengguna dari kalangan generasi muda tidak mengetahui dan memahami makna leksikon tersebut dan penggunaannya.

(3-8) karas

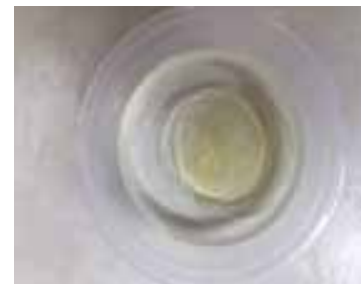

(Foto I Made Netra, 2018)
Sejenis ramuan yang terbuat dari air, dan atau benda cair lainnya, seperti air kelapa yang dipakai sebagai obat sakit kepala yang sengaja dihirup melalui hidung sehingga si pasien akan merasa lebih tenang

Sebagai obat tradisional yaitu obat sakit kepala, karas hanya digunakan di daerah pedesaan dan penggunaannya sebagai obat tradisional penghilang sakit kepala yang membandel tetapi tidak ditemukan dan digunakan di kota lagi. Dengan demikian, dapat dikatakan bahwa pengguna dari kalangan generasi muda tidak mengetahui dan memahami makna leksikon tersebut dan penggunaannya. 
(3-9)

\section{Panawar}

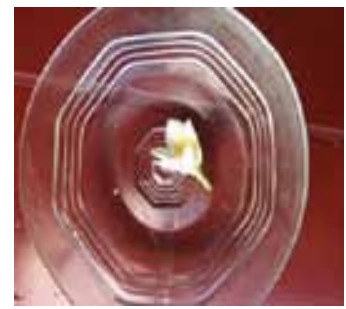

(FotoI Made Netra, 2018)
Sejenis ramuan yang terbuat dari air (kadang minyak) yang biasanya diberikan untuk diminum dan atau dipercikkan kepada orang yang sakit, untuk menghalau sakitnya, biasanya sebelum digunakan air tersebut didoakan atau diberi kekuatan dengan mantra. Sakit yang biasanya diberikan obat panawar adalah sakit yang terkait dengan sakit tulang atau tukang urut.

Sebagai obat tradisional, panawar hanya ditemukan dan digunakan di daerah pedesaan dan penggunaannya sebagai obat tradisional penghilang sakit yang diminumkan dan dipercikkan kepada orag yang sakit tetapi tidak ditemukan dan digunakan di kota lagi. Dengan demikian, dapat dikatakan bahwa pengguna dari kalangan generasi muda tidak mengetahui dan memahami makna leksikon tersebut dan penggunaannya.

(3-10) asaban

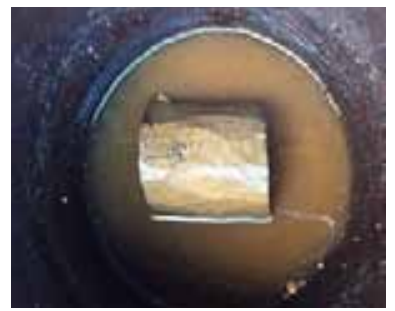

(Fotol Made Netra, 20198)
Sejenis ramuan yang terbuat dari air gosokan benda (bahan obat) seperti kayu cendana yang digosokkan dengan air tersebut sampai berwarna keruh, ramuan jenis ini digunakan sebagai obat luar yang dioleskan pada bagian tubuh yang terluka atau lebam dan keseleo.

Sebagai obat tradisional, asaban hanya ditemukan dan digunakan di daerah pedesaan dan penggunaannya sebagai obat tradisional penghilang sakit yang digosokan pada bagiann tubuh yang lebam dan keseleo tetapi tidak ditemukan dan digunakan di kota lagi. Dengan demikian, dapat dikatakan bahwa pengguna dari kalangan generasi muda tidak mengetahui dan memahami makna leksikon tersebut dan penggunaannya. 
Hlm. 449-474

(3-11) Kumkuman

Menemukenali Leksikon-leksikon Arkais pada Bidang Obat-obatan...

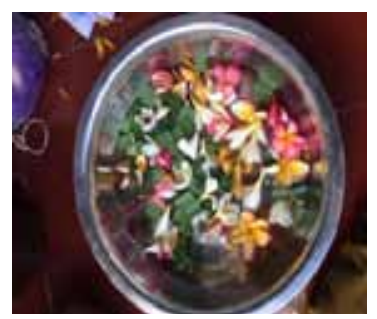

Sejenis ramuan yang terbuat dari air yang berisi berbagai bunga harum yang berfungsi sebagai obat luar untuk menghilangkan penyakit kulit, seperti cacar air.

(FotoI Made Netra, 2018)

Sebagai obat tradisional, kumkuman hanya ditemukan dan digunakan di daerah pedesaan dan penggunaannya sebagai obat tradisional penghilang sakit kulit tetapi tidak ditemukan dan digunakan di kota lagi. Dengan demikian, dapat dikatakan bahwa pengguna dari kalangan generasi muda tidak mengetahui dan memahami makna leksikon tersebut dan penggunaannya.

\subsection{Konfigurasi Leksikon Arkais Bidang Obat-obatan Tradisional Bali}

'Konfigurasi' adalah penjelasan dan penjabaran makna budaya dengan teknik parafrase sehingga tidak terjadi bias budaya. Penjelasaan yang dilakukan tidak berputar-putar. Model yang dipakai untuk melakukan penjabaran makna budaya adalah cultural scripts 'wacana budaya' dengan kategori low level scripts yang memakai eksponen jika, apabila, dsb. Jadi, penjelasan makna akan menjadi tuntas. Berikut adalah contoh eksponen penjelasan dengan teknik cultural scripts:"hal ini bagus jika........", "'hal ini tidak bagus jika........", dsb.

Berdasarkan hasil wawancara dengan informan diperoleh beberapa informasi terkait penjelasan dan konfigurasi makna leksikon (Lihat Tabel 1). Informasi tersebut adalah berupa eksponen makna, seperti deskripsi bentuk, cara/mekanisme/ proses pembuatan atau pengolahannya, hasil, dan fungsinya. Informasi selanjutya adalah berupa komponen yang dipakai untuk menjelaskan dan mengonfigurasi makna, yaitu "jika.....maka". 


\section{Tabel 1 Eksponen Makna Leksikon Arkais Bidang Obat-obatan} Tradisional Bali

\begin{tabular}{|c|c|c|c|c|}
\hline No & Entitas & Cara Pengolahan & Hasil & $\begin{array}{l}\text { Fungsi dan Cara } \\
\text { Pemakaian }\end{array}$ \\
\hline 1 & Borèh & $\begin{array}{l}\text { Diulek di atas batu } \\
\text { dan bisa dicampur } \\
\text { air secukupnya }\end{array}$ & $\begin{array}{l}\mathrm{H} \text { a } 1 \mathrm{u} \mathrm{s}, \\
\text { le } \mathrm{m} \mathrm{b} \text { e } \mathrm{k}, \\
\text { dan basah }\end{array}$ & $\begin{array}{l}\text { Lulur basah dan dilulurkan } \\
\text { ke sekujur tubuh }\end{array}$ \\
\hline 2 & pupuk & $\begin{array}{l}\text { Diulek di atas batu } \\
\text { dan bisa dicampur } \\
\text { air secukupnya }\end{array}$ & $\begin{array}{l}\text { H a } 1 \text { u s, } \\
1 \text { e } \mathrm{m} \mathrm{b} \text { e } \mathrm{k} \\
\text { dan basah }\end{array}$ & $\begin{array}{l}\text { Lulur basah dan hanya } \\
\text { dapat ditempelkan pada } \\
\text { ubun-ubun saja }\end{array}$ \\
\hline 3 & tèrèk & $\begin{array}{l}\text { Diulek di atas batu } \\
\text { dan bisa dicampur } \\
\text { air secukupnya }\end{array}$ & $\begin{array}{l}\text { H a } 1 \text { u s, } \\
\text { le } \mathrm{m} \mathrm{be} \mathrm{k}, \\
\text { dan basah }\end{array}$ & $\begin{array}{l}\text { Lulur basah dan hanya } \\
\text { dapat dioleskan pada } \\
\text { bagian dahi }\end{array}$ \\
\hline 4 & odak & $\begin{array}{l}\text { Diulek di atas batu } \\
\text { tanpa dicampur } \\
\text { air sehingga bisa } \\
\text { diayak }\end{array}$ & $\begin{array}{l}\text { Halus dan } \\
\text { kering }\end{array}$ & $\begin{array}{l}\text { Bedak kering dan hanya } \\
\text { dapat digunakan sebagai } \\
\text { bedak saja }\end{array}$ \\
\hline 5 & simbuh & 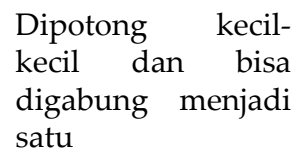 & $\begin{array}{l}\text { Kecil dan } \\
\text { beragam }\end{array}$ & $\begin{array}{l}\text { Sebagai obat kunyah dan } \\
\text { obat luar yang hanya bisa } \\
\text { disemburkan ke bagian } \\
\text { tubuh yang sakit }\end{array}$ \\
\hline 6 & loloh & $\begin{array}{l}\text { Diremas } \\
\text { disaring }\end{array}$ & $\begin{array}{l}\text { Cair dan } \\
\text { berwarna }\end{array}$ & $\begin{array}{ll}\text { Obat dalam yang } & \text { hanya } \\
\text { bisa diminum } & \text { untuk } \\
\text { menghilangkan } & \text { panas } \\
\text { dalam } & \end{array}$ \\
\hline 7 & tutuh & Dicampur & $\begin{array}{l}\text { Cair dan } \\
\text { bening }\end{array}$ & $\begin{array}{l}\text { Obat isap yang hanya bisa } \\
\text { disedot untuk menghalau } \\
\text { sakit kepala }\end{array}$ \\
\hline 8 & karas & Dicampur & $\begin{array}{l}\text { Cair dan } \\
\text { bening }\end{array}$ & $\begin{array}{l}\text { Obat tetes yang hanya bisa } \\
\text { diteteskan ke mata }\end{array}$ \\
\hline 9 & panawar & $\begin{array}{l}\text { Dicampur dan diisi } \\
\text { bunga }\end{array}$ & $\begin{array}{l}\text { Cair dan } \\
\text { bening }\end{array}$ & $\begin{array}{l}\text { Obat cair yang hanya bisa } \\
\text { dipercikan dan diminum }\end{array}$ \\
\hline 10 & asaban & $\begin{array}{lr}\text { Potongan } & \text { kecil } \\
\text { kayu } & \text { cendana } \\
\text { digosok di dalam } \\
\text { mangkok tanah liat }\end{array}$ & $\begin{array}{l}\text { C a i r , } \\
\text { pekat, dan } \\
\text { berwarna }\end{array}$ & $\begin{array}{l}\text { Obat cair yang hanya bisa } \\
\text { dioleskan ke bagian tubuh } \\
\text { yang sakit }\end{array}$ \\
\hline 11 & kumkuman & $\begin{array}{l}\text { Dicampur dan disi } \\
\text { berbagai bunga } \\
\text { harum }\end{array}$ & $\begin{array}{l}\text { Cair dan } \\
\text { bening }\end{array}$ & $\begin{array}{l}\text { Obat cair yang hanya bisa } \\
\text { dimandikan ke tubuh }\end{array}$ \\
\hline
\end{tabular}

Oleh karena itu, berikut diberikan beberapa contoh konfigurasi leksikon. 
borèh

$\mathrm{X}$ adalah sesuatu

$X$ dibuat dari campuran berbagai bahan dari daun-daunan, akar-akaran, ranting pohon, kulit pohon, dan umbi-umbian dan rempah-rempah

$X$ diulek sampai halus pada tempat tertentu yang terbuat dari batu

Setiap saat $X$ dapat ditambahkan air secukupnya

$X$ berfungsi sebagai lulur

$X$ dapat dipakai pada sekujur tubuh bagian luar saja atau pada bagian tubuh yang sakit saja

X dapat dipakai dengan cara mengoleskan atau melulurkannya dengan tangan

Seseorang berpikir seperti ini:

“Jika $X$ digunakan secara rutin, maka sesuatu yang baik pasti terjadi"

Oleh karena itu:

Seseorang menyebut benda ini dengan boreh.

Berdasarkan hasil wawancara, borèh memiliki variasi bentuk, seperti pupuk dan tèrèk yang perbedaannya tampak pada cara pemakaiannya saja. Variasi yang lain adalah odak yang merupakan bedak kering

simbuh

$X$ adalah sesuatu

$X$ dibuat dari bahan berupa daun-daunan dan pohon-pohonan

$X$ dipotong kecil-kecil

$\mathrm{X}$ biasanya dapat dicampur dengan garam

$X$ berfungsi sebagai obat tradisional

Seseorang berpikir seperti ini:

"Jika saya dalam kondisi sakit atau kurang enak badan,

alangkah baiknya menggunakan obat ini"

"Kalau tidak sesuatu yang tidak baik akan terjadi"

$X$ hanya dapat dipakai pada bagian tubuh luar yang 
dirasakan sakit

$X$ dapat dipakai dengan cara mengunyah dan

menyemburkannya

Seseorang berpikir seperti ini:

"Jika X digunakan secara rutin, maka sesuatu yang baik pasti terjadi"

Oleh karena itu:

Seseorang menyebut benda ini dengan simbuh.

loloh

$\mathrm{X}$ adalah sesuatu

$\mathrm{X}$ berbentuk cair dan berwarna dan agak keruh

$X$ dibuat dari daun tertentu

$X$ diremas dengan tangan dalam sebuah wadah yang berisi air

$X$ diremas selama beberapa waktu secara terus menerus

Selang beberapa saat $X$ disaring sedemikian rupa dan

dilakukan berulang ulang

$\mathrm{X}$ berfungsi sebagai obat panas dalam

$\mathrm{X}$ dapat diminum

Seseorang berpikir seperti ini:

"Jika saya merasa panas dalam, maka alangkah bagusnya

saya minum ini"

"Jika tidak, sesuatu yang lebih buruk dapat terjadi"

Oleh karena itu:

Seseorang menyebut benda ini dengan loloh.

tutuh

$\mathrm{X}$ adalah sesuatu

$\mathrm{X}$ berbentuk cair

$X$ dibuat dari getah pohon

$X$ berfungsi sebagai obat tradisional untuk sakit kepala

Seseorang berpikir seperti ini:

"Jika saya mengalami sakit kepala berat, alangkah baiknya menggunakan obat ini"

"Kalau tidak sesuatu yang tidak baik akan terjadi" 
$X$ hanya dapat digunakan sebagai obat tetes

$X$ hanya dapat digunakan dengan sengaja

$X$ dapat digunakanberulang kali sampai si pasien merasa

lebih tenang

Oleh karena itu:

Seseorang menyebut benda ini dengan tutuh.

Ada satu variasi dari tutuh yaitu karas yang perbedaannya terlihat dari cara pemakainnya saja.

Berikut adalah konfigurasi leksikon yang berfungsi sebagai obat cair.

asaban

$\mathrm{X}$ adalah sesuatu

$\mathrm{X}$ sejenis ramuan yang terbuat dari air gosokan benda

(bahan obat) seperti kayu cendana

$\mathrm{X}$ digosokkan dengan air sampai berwarna keruh berwarna keruh

$\mathrm{X}$ digunakan sebagai obat luar

$\mathrm{X}$ dioleskan pada bagian tubuh yang terluka atau lebam dan keseleo

Seseorang berpikir seperti ini:

"Jika saya merasa sakit lebam, lecet dan keseleo, maka alangkah bagusnya saya menggunakan ini" "Jika tidak, sesuatu yang lebih buruk dapat terjadi" Oleh karena itu:

Seseorang menyebut benda ini dengan asaban.

\section{Simpulan}

Dari pembahasan terhadap kedua aspek dalam artikel ini, maka dapat disimpulkan hal-hal sebagai berikut.

Pertama, leksikon arkais pada praktik budaya Bali bidang obat-obatan tradisional Bali dapat diidentifikasikan berdasarkan pengguna dari kalangan generasi muda dan letak geografi. Dilihat dari pengguna darikalangan generasi muda diketahuibahwa mereka 
tidak mengetahui konsep leksikon tersebut dan tidak mengetahui keberadaan artefaknya. Dilihat dari letak geografisnya, leksikon arkais bidang obat-obatan masih ada dan digunakan di daerah pedesaan tetapi tidak digunakan lagi di daerah perkotaan. Ada sebelas (11) buah leksikon bidang obat-obatan yang dikategorikan arkais berdasarkan pengguna dari kalangan generasi muda dan letak geografi (ditemukan dan digunakan di daerah pedesaan dan tidak ada di daerah perkotaan).

Kedua, konfigurasi makna leksikon arkais tersebut dibuat berdasarkan model Cultural Scripts, dengan memakai komponen "jika...maka", dengan deskripsi eksponen berupa, bentuk, cara/ mekanisme/proses pembuatan atau pengolahannya, hasil, dan fungsinya.

\section{Ucapan Terima Kasih}

Dalam kesempatan ini, ucapan terima kasih yang tulus dan mendalam disampaikan kepada Rektor Universitas Udayana, Ketua LPPM Universitas Udayana, Dekan Fakultas Ilmu Budaya, Koordinator Prodi Sastra Inggris, Fakultas Ilmu Budaya, Universitas Udayana karena telah memberikan kesempatan dan mendanai penelitian Invensi Udayana. Ucapan terima kasih yang tidak terhingga juga disampaikan kepada para informan dan informan kunci, pembantu peneliti, laboran peneliti yang tidak bisa disebutkan satu per satu karena telah banyak terlibat dan membantu banyak sehingga penelitian telah selesai dilaksanakan dan sampai artikel ini bisadiselesaikan sesuai dengan yang diharapkan.

\section{Daftar Pustaka}

Aitchison, Jean. 1994. Words in Mind. Cambridge: Blackwell Publisher.

Allan, Keith. 2002. Natural Language Semantics. Oxford: Blackwell Publisher.

Bungin, Burhan. 2003. Analisis Data Penelitian Kualitatif. Pemahaman Filosofis dan Metodologis ke Arah Penguasaan Model Aplikasi. Jakarta: PT Raja Grafindo Persada. 
Darheni, Nani. 2011. "Dinamika Perkembangan Kosakata Bahasa Indonesia Ditinjau Dari Aspek Pemaknaan” dalam Jurnal Sosioteknologi Edisi 23 Tahun 10, Agustus 2011.

Goddard, Cliff. 1994. "Semantic Theory and Semantic Universal" Dalam Cliff Goddard and A.Wierzbicka (eds), from Semantic and Lexical Universals: Theory and Empirical Findings. Amsterdam/Philadelphia: Benjamins, 7--29.

Goddard, Cliff. 2004. Cross Linguistic Syntax from A Semantic Point of View (NSM Approach). New England: New England University Press.

Holmes, Janet. 2013. An Introduction to Sociolingustics. USA: Routledge Taylor and Francis Group

Karagulova. et all. 2016. "Linguocultural Description and Formation of Archaic Words".Indian Journal of Scince and Tecnology.http://www. xlinguae.eu/files/XLinguae3_2016_(Diakses Januari 21, 2018).

Moleong, Lexy J. 2000. Metodologi Penelitian Kualitatif. Bandung: PT Remaja Rosdakarya.

Netra, I Made. 2014. “Explication and Configuration of Balinese Cultural Script Meanings"dalam Prosiding Kongres Internasional Masyarakat Linguistik Indonesia. Bandar Lampung: Universitas Lampung bekerja sama dengan MLI.

Netra, I Made. 2018. “Dokumentasi Visual Statis Leksikon-Leksikon Arkais pada Renik Budaya Bali dan Padanannya dalam Bahasa Inggris". Penelitian Hibah Invensi Udayana tahun 2018. Depasar: LPPM Universitas Udayana.

Netra, I Made, dkk. 2018. Glosarium: Kata dan Istilah Prototipe Primitiva Semantik Bidang Agama dan Adat Bali. Denpasar: Cakra Media Utama.

Rina, Pamantung. 2015. "Taksonomi Nomina Aspek Makanan dan Minuman Khas Minahasa" (Desertasi). Denpasar: Program Doktor (S3) Linguistik, Program Pascasarjana Universitas Udayana.

Nuthihar, Rahmad. 2016. Revitalisasi Kosa Kata Arkais. Jakarta: Badan Pengembangan dan Pembinaan Bahasa.

Suardiana, I Wayan. 2012. "Bahasa Bali dan Pemertahanan Kearifan Lokal" dalam Linguistika Pengembang Cakrawala Linguistik. Vol. 19, No. 36 Maret 2012. Denpasar: Program Studi Magister (S3) Linguistik Universitas Udayana bekerjasama dengan Asosiasi Peneliti Bahasa-bahasa Lokal (APBL).

Sudaryanto. 1993. Medode dan Aneka Teknik Analisis Bahasa: Penganlar 
penelilianWahana Kehudayaan Secara Linguilis. Yogyakarta: Duta Wacana University Press.

Wahab, Andi Abdul. 2015. "Arkais dalam Bahasa Melayu Jambi di Kabupaten Sarolangun: Kajian Deskriptif".http://repository.unja. ac.id/2014/1/artikel\%20bahasa\%20indonesia.pdf (Diakses Januari 21, 2018.

Wierzbicka, Anna. 1996. Semantics rimes and Universals. Oxford and New York: Oxford University Press.

Wierzbicka, Anna 1999. Emotions Across Languages and Cultures: Diversity andUniversals. Cambridge: Cambridge University Press.

Yulis, E. dkk. 2013. “An Analysis Of Dead Words Of Minangkabaunese In Koto Tabang-Pariaman Dialect". http://scholar.google.co.id/citations?user= 2yaIe7oAAAAJ\&hl=id Diakses Januari 21, 2018.

\section{LAMPIRAN}

\section{Daftar Leksikon Arkais Berbagai Bidang Praktik Budaya Bali}

\begin{tabular}{|c|c|c|c|c|c|}
\hline No & Leksikon & Bidang & No & Leksikon & Bidang \\
\hline 1 & $\begin{array}{l}\text { Angkul- } \\
\text { angkul }\end{array}$ & Arsitektur & 89 & Borèh & Obat-Obatan \\
\hline 2 & Apad & Arsitektur & 90 & Loloh & Obat-Obatan \\
\hline 3 & Bada & Arsitektur & 91 & Odak & Obat-Obatan \\
\hline 4 & Balè & Arsitektur & 92 & Simbuh & Obat-Obatan \\
\hline 5 & Lèneng & Arsitektur & 93 & Tutuh & Obat-obatan \\
\hline 6 & Rurung & Arsitektur & 94 & Karas & Obat-obatan \\
\hline 7 & Sake & Arsitektur & 95 & Terek & Obat-obatan \\
\hline 8 & Sendi & Arsitektur & 96 & Pupuk & Obat-obatan \\
\hline 9 & Ampik & Arsitektur & 97 & kumkuman & Obat-obatan \\
\hline 10 & Kubu & Arsitektur & 98 & Asaban & Obat-obatan \\
\hline 11 & Paon & Arsitektur & 99 & Panawar & Obat-obatan \\
\hline 12 & Tebe & Arsitektur & 100 & Alutan & Peralatan Rumah Tangga \\
\hline 13 & Sengauk & Makanan/Minuman & 101 & Aon & Peralatan Rumah Tangga \\
\hline 14 & Abug & Makanan/Minuman & 102 & Baneh & Peralatan Rumah Tangga \\
\hline 15 & aron-aron & Makanan/Minuman & 103 & Bonjor & Peralatan Rumah Tangga \\
\hline 16 & banyu & Makanan/Minuman & 104 & Semeti & Peralatan Rumah Tangga \\
\hline 17 & Calon & Makanan/Minuman & 105 & Bodag & Peralatan Rumah Tangga \\
\hline 18 & telengis & Makanan/Minuman & 106 & bungut paon & Peralatan Rumah Tangga \\
\hline 19 & enteban & Makanan/Minuman & 107 & Damar & Peralatan Rumah Tangga \\
\hline 20 & Entip & Makanan/Minuman & 108 & Dampar & Peralatan Rumah Tangga \\
\hline 21 & ketekan & Makanan/Minuman & 109 & Galar & Peralatan Rumah Tangga \\
\hline 22 & Lempog & Makanan/Minuman & 110 & Gebeh & Peralatan Rumah Tangga \\
\hline 23 & Lud & Makanan/Minuman & 111 & Gombang & Peralatan Rumah Tangga \\
\hline 24 & Pasung & Makanan/Minuman & 112 & Ilih & Peralatan Rumah Tangga \\
\hline
\end{tabular}




\begin{tabular}{|c|c|c|c|c|c|}
\hline 25 & $\begin{array}{l}\text { pulung- } \\
\text { pulung }\end{array}$ & Makanan/Minuman & 113 & Jalikan & Peralatan Rumah Tangga \\
\hline 26 & Titisan & Makanan/Minuman & 114 & Jeding & Peralatan Rumah Tangga \\
\hline 27 & Tombong & Makanan/Minuman & 115 & Jembor & Peralatan Rumah Tangga \\
\hline 28 & Sisilan & Makanan/Minuman & 116 & Caratan & Peralatan Rumah Tangga \\
\hline 29 & Usam & Makanan/Minuman & 117 & Kelambi & Peralatan Rumah Tangga \\
\hline 30 & Tepeng & Makanan/Minuman & 118 & Kèlè & Peralatan Rumah Tangga \\
\hline 31 & bumbung & $\begin{array}{l}\text { Olah Raga/Per- } \\
\text { mainan }\end{array}$ & 119 & Klèngang & Peralatan Rumah Tangga \\
\hline 32 & Cèèng & $\begin{array}{l}\text { Olah Raga/Per- } \\
\text { mainan }\end{array}$ & 120 & Kobokan & Peralatan Rumah Tangga \\
\hline 33 & Kisa & $\begin{array}{l}\text { Olah Raga/Per- } \\
\text { mainan }\end{array}$ & 121 & Kukusan & Peralatan Rumah Tangga \\
\hline 34 & Setipan & $\begin{array}{l}\text { Olah Raga/Per- } \\
\text { mainan }\end{array}$ & 122 & Lesung & Peralatan Rumah Tangga \\
\hline 35 & Taji & $\begin{array}{l}\text { Olah Raga/Per- } \\
\text { mainan }\end{array}$ & 123 & Elu & Peralatan Rumah Tangga \\
\hline 36 & Tajog & $\begin{array}{l}\text { Olah Raga/Per- } \\
\text { mainan }\end{array}$ & 124 & Ngaad & Peralatan Rumah Tangga \\
\hline 37 & Tulupan & $\begin{array}{l}\text { Olah Raga/Per- } \\
\text { mainan }\end{array}$ & 125 & Pabuan & Peralatan Rumah Tangga \\
\hline 38 & bèngol & $\begin{array}{l}\text { Olah Raga/Per- } \\
\text { mainan }\end{array}$ & 126 & Panglocokan & Peralatan rumah tangga \\
\hline 39 & Cuplag & $\begin{array}{l}\text { Olah Raga/Per- } \\
\text { mainan }\end{array}$ & 127 & Palungan & Peralatan Rumah Tangga \\
\hline 40 & gangsing & $\begin{array}{l}\text { Olah Raga/Per- } \\
\text { mainan }\end{array}$ & 128 & Pengrètan & Peralatan Rumah Tangga \\
\hline 41 & $\begin{array}{l}\text { motor-mo- } \\
\text { toran }\end{array}$ & $\begin{array}{l}\text { Olah Raga/Per- } \\
\text { mainan }\end{array}$ & 129 & $\begin{array}{l}\text { Penguligan } \\
\text { borèh }\end{array}$ & Peralatan Rumah Tangga \\
\hline 42 & Tambah & Alat Pertanian & 130 & Penyeluhan & Peralatan Rumah Tangga \\
\hline 43 & Carik & Alat Pertanian & 131 & Pulu & Peralatan Rumah Tangga \\
\hline 44 & dungki & Alat Pertanian & 132 & Sèmprong & Peralatan Rumah Tangga \\
\hline 45 & Jineng & Alat Pertanian & 133 & Sentir & Peralatan Rumah Tangga \\
\hline 46 & Grèjag & Alat Pertanian & 134 & Sidu & Peralatan Rumah Tangga \\
\hline 47 & Uge & Alat Pertanian & 135 & Sundih & Peralatan Rumah Tangga \\
\hline 48 & Lampit & Alat Pertanian & 136 & Sepit & Peralatan Rumah Tangga \\
\hline 49 & Madik & Alat Pertanian & 137 & Sereg & Peralatan Rumah Tangga \\
\hline 50 & Pemlasah & Alat Pertanian & 138 & Sabet & Peralatan Rumah Tangga \\
\hline 51 & Penampad & Alat Pertanian & 139 & kikihan & Peralatan Rumah Tangga \\
\hline 52 & Pengrèdègan & Alat Pertanian & 140 & Tapih & Peralatan Rumah Tangga \\
\hline 53 & Plèting & Alat Pertanian & 141 & Calung & Peralatan Rumah Tangga \\
\hline 54 & Por & Alat Pertanian & 142 & cangkir kawu & Peralatan Rumah Tangga \\
\hline 55 & Arit & Alat Pertanian & 143 & Kawu & Peralatan Rumah Tangga \\
\hline 56 & Tampus & Alat Pertanian & 144 & Kekeb & Peralatan Rumah Tangga \\
\hline 57 & Tengala & Alat Pertanian & 145 & Pengedangan & Peralatan Rumah Tangga \\
\hline 58 & Gelanggang & Alat Pertanian & 146 & piring tanah & Peralatan Rumah Tangga \\
\hline 59 & Serat & Alat Pertanian & 147 & sinduk nasi & Peralatan Rumah Tangga \\
\hline 60 & Sèsèr & Alat Pertanian & 148 & Sloki kayu & Peralatan Rumah Tangga \\
\hline 61 & Singkad & Alat Pertanian & 149 & Tika & Peralatan Rumah Tangga \\
\hline 62 & Sorok & Alat Pertanian & 150 & Amed & $\begin{array}{l}\text { Peralatan Upacara Adat dan } \\
\text { Agama }\end{array}$ \\
\hline
\end{tabular}




\begin{tabular}{|c|c|c|c|c|c|}
\hline 63 & Angapan & Alat Pertanian & 151 & Canting & $\begin{array}{l}\text { Peralatan Upacara Adat dan } \\
\text { Agama }\end{array}$ \\
\hline 64 & Blida & Alat Pertanian & 152 & Sibuh & $\begin{array}{l}\text { Peralatan Upacara Adat dan } \\
\text { Agama }\end{array}$ \\
\hline 65 & Beliung & Alat Pertanian & 153 & Sunari & $\begin{array}{l}\text { Peralatan Upacara Adat dan } \\
\text { Agama }\end{array}$ \\
\hline 66 & Bubu & Alat Pertanian & 154 & Takir & $\begin{array}{l}\text { Peralatan Upacara Adat dan } \\
\text { Agama }\end{array}$ \\
\hline 67 & Camok & Alat Pertanian & 155 & Wanci & $\begin{array}{l}\text { Peralatan Upacara Adat dan } \\
\text { Agama }\end{array}$ \\
\hline 68 & Gahangan & Alat Pertanian & 156 & Keren & Peralatan Upacara dan agama \\
\hline 69 & Gegilik & Alat Pertanian & 157 & ketu & $\begin{array}{l}\text { Peralatan upacara adat dan } \\
\text { agama }\end{array}$ \\
\hline 70 & Gegiring & Alat Pertanian & 158 & Dulang & $\begin{array}{l}\text { Peralatan Upacara Adat dan } \\
\text { Agama }\end{array}$ \\
\hline 71 & Janggi & Alat Pertanian & 159 & jun tandeg & $\begin{array}{l}\text { Peralatan Upacara Adat dan } \\
\text { Agama }\end{array}$ \\
\hline 72 & Kepuakan & Alat Pertanian & 160 & kampuh & Peralatan Upacara dan agama \\
\hline 73 & Kiskis & Alat Pertanian & 161 & umpal & $\begin{array}{l}\text { Peralatan upacara adat dan } \\
\text { agama }\end{array}$ \\
\hline 74 & Koncongan & Alat Pertanian & 162 & Kulkul & $\begin{array}{l}\text { Peralatan Upacara Adat dan } \\
\text { Agama }\end{array}$ \\
\hline 75 & Capil & Alat Pertanian & 163 & Kumba & $\begin{array}{l}\text { Peralatan Upacara Adat dan } \\
\text { Agama }\end{array}$ \\
\hline 76 & Gerip & Pendidikan & 164 & Kun & Peralatan Upacara dan agama \\
\hline 77 & Karas & Pendidikan & 165 & Payuk & $\begin{array}{l}\text { Peralatan upacara adat dan } \\
\text { agama }\end{array}$ \\
\hline 78 & patlut & Pendidikan & 166 & Pinjekan & $\begin{array}{l}\text { Peralatan Upacara Adat dan } \\
\text { Agama }\end{array}$ \\
\hline 79 & gedebeg & Transportasi & 167 & Saab & $\begin{array}{l}\text { Peralatan Upacara Adat dan } \\
\text { Agama }\end{array}$ \\
\hline 80 & Dokar & Transportasi & 168 & Senden & $\begin{array}{l}\text { Peralatan Upacara Adat dan } \\
\text { Agama }\end{array}$ \\
\hline 81 & janggolan & Transportasi & & & \\
\hline 82 & Jaran & Transportasi & & & \\
\hline 83 & jukung & Transportasi & & & \\
\hline 84 & Kodang & Perdagangan & & & \\
\hline 85 & Pataan & Perdagangan & & & \\
\hline 86 & Kècèr & Perdagangan & & & \\
\hline 87 & Kèpè & Perdagangan & & & \\
\hline 88 & pis bolong & Perdagangan & & & \\
\hline
\end{tabular}

